\title{
Uji Keefektifan Antijamur Ekstrak Air Rimpang Lengkuas (Alpinia galanga [L] Willd.) sebagai Perlakuan Pratanam untuk Mengendalikan Colletotrichum spp. pada Kedelai (Glycine max L.)
}

\author{
Endah Yulia ${ }^{{ }^{*}}$, Tarkus Suganda ${ }^{1}$, Fitri Widiantini ${ }^{1}$ dan Rangga Irawan Prasetyo ${ }^{2}$ \\ ${ }^{1}$ Departemen Hama dan Penyakit Tumbuhan, Fakultas Pertanian, Universitas Padjadjaran \\ Jl. Raya Bandung-Sumedang KM 21, Jatinangor 40600 \\ ${ }^{2}$ Alumni Departemen HPT, Fakultas Pertanian, Universitas Padjadjaran \\ *Alamat korespondensi: endah.yulia@unpad.ac.id
}

\begin{abstract}
Antifungal Effect of Aqueous Extract of Galangal (Alpinia galanga [L] Willd.) Rhizome as Seed Treatment to Control Colletotrichum spp. of Soybean (Glycine max L.)
\end{abstract}

Colletotrichum is one of the most important seed-borne pathogens of soybean which is usually controlled with synthetic fungicide seed treatment. However, it is believed that the use of synthetic fungicide can cause a variety of negative impacts to the environment and human health. Galangal rhizome extract has been widely reported to have antifungal and antibacterial properties. The aim of the study was to investigate the effectiveness of galangal rhizome aqueous extract as antifungal for pre-planting seed treatment to control Colletotrichum spp. in soybean. Laboratory and glasshouse experiments were carried out at the Department of Plant Pests and Diseases, Faculty of Agriculture, Universitas Padjadjaran. The method used was an experimental method to test the effectiveness of galangal rhizome aqueous extract against the emergence and spore germination suppression of Colletotrichum spp., and to test the seed viability and plant growth of soybean. Galangal rhizome extract with concentrations of $10 \%$, $30 \%, 50 \%, 70 \%, 90 \%$ and $100 \%$ as well as a metalaxyl fungicide $(0.5 \mathrm{~g} / \mathrm{l})$ were applied as a seed treatment. The results showed galangal rhizome aqueous extract at concentration of $100 \%$ reduced the presence of Colletotrichum spp. in seeds up to $100 \%$ after the treatment and suppressed the spore germination by $76.20 \%$ as well as increased the seed viability and the growth of soybean plants.

Keywords: Alpinia galanga, aqueous extract, seed treatment, soybean, Colletotrichum spp.

\begin{abstract}
ABSTRAK
Umumnya pengendalian penyakit tular benih pada kedelai dilakukan melalui perlakuan benih dengan menggunakan fungisida sintetik yang diakui dapat menimbulkan berbagai dampak negatif pada lingkungan maupun kesehatan manusia. Penggunaan ekstrak air rimpang lengkuas untuk perlakuan benih dapat diterapkan sebagai alternatif pengendalian penyakit tular benih pada kedelai. Lengkuas telah banyak dilaporkan memiliki sifat antijamur dan antibakteri. Penelitian ini dilaksanakan dengan tujuan untuk mengetahui keefektifan ekstrak air rimpang lengkuas sebagai antijamur untuk perlakuan benih dalam mengendalikan penyakit tular benih pada kedelai. Percobaan dilaksanakan di Laboraturium Fitopatologi dan rumah kaca Departemen Hama dan Penyakit Tumbuhan, Fakultas Pertanian, Universitas Padjadjaran. Metode penelitian yang digunakan adalah metode eksperimen dengan pengujian keefektifan air persaan rimpang lengkuas terhadap kemunculan, penekanan perkecambahan konidia, uji pertumbuhan benih, dan viabilitas benih jamur Colletotrichum spp. pada kedelai. Ekstrak air rimpang lengkuas dengan konsentrasi 10\%; 30\%; 50\%; 70\%; 90\%; dan 100\% serta fungsida berbahan aktif metalaksil $(0,5 \mathrm{~g} / \mathrm{l})$ diaplikasikan sebagai perlakuan benih kedelai. Hasil percobaan menunjukkan ekstrak air rimpang lengkuas konsentrasi 100\% dapat menekan sampai 100\% kemunculan Colletotrichum spp. setelah
\end{abstract}


perlakuan benih, menekan perkecambahan konidia sebesar $76,20 \%$ serta meningkatkan pertumbuhan dan viabilitas benih kedelai.

Kata kunci: engkuas, ekstrak air, perlakuan benih, kedelai, Colletotrichum spp.

\section{PENDAHULUAN}

Kedelai (Glycine max L.) merupakan salah satu sumber protein nabati yang mengandung $40-$ $45 \%$ protein, $18-20 \%$ minyak, $24-26 \%$ karbohidrat dan beberapa vitamin yang baik untuk kesehatan (Shovan et al., 2008). Oleh karena itu penyediaan kedelai yang cukup dapat membantu pemenuhan kebutuhan masyarakat akan sumber protein. Salah satu faktor yang berpengaruh terhadap produktivitas tanaman kedelai adalah kualitas benih yang digunakan pada waktu penanaman dimana kerugian yang sangat besar sering terjadi akibat penggunaan benih yang kualitasnya tidak baik yang akan menurunkan hasil panen (Munkvold et al., 2006; Sutopo, 1985). Oleh karena itu, benih yang berkualitas baik menjadi hal yang sangat penting di dalam budidaya kedelai. Kualitas suatu benih diantaranya dipengaruhi oleh keberadaan mikrob pada benih tersebut baik berupa mikrob patogen ataupun kontaminan. Semua mikrob patogen seperti jamur, bakteri, virus, dan nematoda dapat terbawa oleh benih, baik itu karena benihnya terinfeksi maupun terinfestasi (Sawatwanich et al., 2007).

Jamur Colletotrichum spp. merupakan patogen penyebab penyakit antraknosa pada kedelai. Penyakit antraknosa mampu menurunkan produksi dan kualitas kedelai dimana penyakit ini berkembang dari mulai kedelai dipanen sampai di tempat penyimpanan (Shovan et al., 2008). Genus Colletotrichum merupakan kelompok utama patogen yang bisa terbawa benih (seed-borne) atau patogen yang ditransmisikan melalui benih kedelai. Dengan demikian, apabila benih kedelai yang sudah terinfeksi jamur ini atau jika benih yang digunakan berasal dari tanaman kedelai yang telah terinfeksi antraknosa maka kedelai yang dihasilkan akan menurun kualitasnya (Hartman et al., 1986). Benih yang terlihat bersih dan sehat keadaannya belum tentu bebas dari patogen penyebab penyakit karena patogen dapat berada di dalam benih (Kartasapoetra, 2003). Maka, perlakuan benih (seed treatment) merupakan cara yang paling tepat untuk meminimalkan patogen yang terinfestasi pada benih yang akan ditanam. Cara yang paling umum dilakukan dan sangat diutamakan untuk perlakuan benih adalah penggunaan fungisida sintetis
(Munkvold et al., 2006). Tetapi akhir-akhir ini, senyawa kimia asal tumbuhan mulai banyak diteliti sebagai bahan antimikrob alami. Salah satu contohnya adalah tanaman lengkuas (Alpinia galanga L.) yang telah banyak digunakan sebagai bahan sumber senyawa antijamur (Yuharmen et al., 2002; Munkvold et al., 2006; Yulia, 2006; Yulia et al., 2008)

Lengkuas dilaporkan mengandung senyawa golongan flavonoid, fenol dan terpenoid (Yuharmen dkk., 2002). Rimpang lengkuas mengandung kurang lebih $1 \%$ minyak atsiri berwarna kuning kehijauan yang terutama terdiri atas $48 \%$ metil sinamat, 20 $30 \%$ sineol, eugenol, $1 \%$ kamfer, seskuiterpen, dan galangin (Sinaga, 2003). Dalam pengendalian mikrob patogen tumbuhan, ekstrak air dan minyak lengkuas juga telah dilaporkan berpotensi sebagai antimikrob. Keefektifan lengkuas terhadap patogen tumbuhan dilaporkan pada penghambatan 100\% perkecambahan konidia jamur Pestalotiopsis versicolor pada konsentrasi $500 \mathrm{mg} / \mathrm{ml}$ (Yulia, 2006). Dalam penghambatan jamur Colletotrichum, ekstrak air dan etanol lengkuas dilaporkan menghambat sampai $100 \%$ pertumbuhan miselium dan perkecambahan konidia C. gloeosporioides penyebab penyakit antraknosa pada cabai (Yulia et al., 2006). Selain itu, ekstrak jahe yang merupakan famili Zingiberaceae lain dilaporkan dapat menghambat pertumbuhan diameter koloni jamur C. dematium penyebab antraknosa pada kedelai dengan penghambatan pertumbuhan jamur tertinggi hampir 50\% pada konsentrasi tertinggi $20 \%(\mathrm{mg} / \mathrm{ml})$ (Shovan et al., 2008).

Perlakuan benih merupakan salah satu tindakan pengendalian yang sangat penting pada saat pratanam untuk mengurangi kemungkinan infestasi patogen pembawa penyakit ke lapangan yang nantinya dapat mengakibatkan kerugian hasil pertanian. Benih yang terinfeksi patogen atau rusak dapat menimbulkan kerugian secara ekonomi yang cukup besar (Agrios, 1997; Munkvold et al., 2006). Walaupun jumlah benih yang terinfeksi sedikit tetapi sudah dapat menyediakan inokulum yang cukup untuk penyebaran dan infeksi pada tanaman yang nantinya tumbuh dari benih tersebut dan kemudian mengakibatkan kehilangan hasil. Penelitian ini bertujuan untuk mengetahui 
keefektifan ekstrak air rimpang lengkuas sebagai antijamur untuk perlakuan pratanam benih kedelai. Diharapkan konsentrasi terbaik yang diperoleh dapat digunakan sebagai antijamur dan dapat diaplikasikan untuk perlakuan benih kedelai.

\section{BAHAN DAN METODE}

Penelitian dilaksanakan di Laboratorium Fitopatologi dan rumah kaca Departemen Hama dan Penyakit Tumbuhan, Fakultas Pertanian, Universitas Padjadjaran, Jatinangor. Metode yang digunakan yaitu metode percobaan dengan menggunakan rancangan acak lengkap (RAL) yang terdiri atas 8 perlakuan dan 4 kali ulangan yaitu: 10\%; 30\%; 50\%; 70\%; 90\%; 100\% ekstrak air rimpang lengkuas; fungsida berbahan aktif metalaksil $(0,5 \mathrm{~g} / \mathrm{l}$ sebagai pembanding) dan perlakuan kontrol. Untuk mengetahui perbedaan antar rata-rata perlakuan dilakukan Uji Jarak Berganda Duncan pada taraf nyata $5 \%$. Analisis statistik dilakukan dengan menggunakan Program Komputer SPSS Versi 16.0.

\section{Penyediaan Benih Kedelai dan Rimpang Lengkuas}

Benih kedelai diperoleh dari Seed Center Fakultas Pertanian, Universitas Padjadjaran. Benih kedelai berupa benih yang disimpan dari hasil panen dan tidak mendapat perlakuan apapun setelah panen. Rimpang lengkuas segar diperoleh dari Kebun Percobaan Balai Penelitian Tanaman Rempah dan Obat (Balitro) Manoko, Lembang, Jawa Barat. Rimpang lengkuas diperoleh dari Balitro dengan tujuan untuk menjamin ketepatan spesies ataupun varietas yang digunakan dalam penelitian. Ekstrak air rimpang lengkuas disiapkan dengan cara mencuci rimpang lengkuas dengan air kemudian dikeringanginkan di atas kertas tissu selama 24 jam. Setelah 24 jam, rimpang lengkuas diblender dan diperas dengan menggunakan kain muslin kemudian disterilisasi dengan menggunakan saringan millipore (ukuran 0,2 $\mu \mathrm{m}$ ) (Menaka, 2003). Larutan ini dianggap sebagai larutan ekstrak air rimpang lengkuas standar (100\%).

\section{Isolasi Jamur Colletotrichum spp.}

Isolasi jamur Colletotrichum spp. dilakukan melalui metode incubation technique yang dijelaskan dalam Black (1999), Dhingra \& Sinclair (1985), dan Suryanarayana (1979) yaitu dengan mensterilisasi permukaan benih dengan larutan
Klorox 10\%, kemudian menempatkan benih kedelai pada medium Potato Dextrosa Agar (PDA) dan diinkubasikan. Koloni jamur yang tumbuh pada benih kedelai dan teridentifikasi sebagai Colletotrichum spp. kemudian dimurnikan (Dhingra \& Sinclair 1985). Identifikasi dilakukan berdasarkan informasi dari Barnett \& Hunter (1972).

\section{Uji Keefektifan Ekstrak air Rimpang Lengkuas terhadap Colletotrichum spp. pada Benih Kedelai}

Sebanyak 160 benih kedelai direndam di dalam akuades steril selama 30 menit, kemudian dikeringanginkan di atas kertas saring. Setelah kering dimasukkan ke dalam tabung reaksi yang berisi klorox $10 \%$ lalu dikocok agar klorox tersebut dapat membilas benih kedelai secara merata. Setelah itu diangkat dan dikeringkan beberapa menit kemudian dibilas dengan akuades steril untuk menghilangkan sisa-sisa klorox yang menempel pada benih. Benih yang sudah dibilas dikeringanginkan kembali di atas kertas saring, kemudian benih diinokulasi jamur Colletotrichum spp. dengan cara memasukkan benih kedelai tersebut ke dalam Petri dish yang berisi biakan murni Colletotrichum spp. yang berumur minimal 9 hari. Kemudian benih disimpan dalam Petri dish berisi biakan jamur Colletotrichum spp. selama 24 jam. Setelah 24 jam, benih digunakan untuk perlakuan.

Pengujian keefektifan ekstrak air rimpang lengkuas pada benih dilakukan dengan cara merendam benih kedelai yang sudah diinokulasi ke dalam $10 \mathrm{ml}$ ekstrak air rimpang lengkuas pada berbagai konsentrasi $10 \%, 30 \%, 50 \%, 70 \%, 90 \%$, $100 \%$, akuades steril sebagai kontrol, dan fungisida sebagai pembanding selama 30 menit. Kemudian benih yang sudah direndam tersebut dikeringanginkan di atas kertas saring dan diletakkan di atas medium PDA di dalam Petri dish. Dalam satu Petri dish diletakkan masing-masing lima benih kedelai dan dilakukan pengulangan sebanyak empat kali. Setelah 24 jam, persentase kemunculan Colletotrichum spp. pada benih kedelai diamati. Pengamatan dilakukan dengan menghitung persentase kemunculan jamur dan dibandingkan dengan perlakuan kontrol. Pengamatan dimulai setelah 24 jam selama 7 hari.

\section{Uji Penekanan Perkecambahan Konidia Colletotrichum spp.}

Uji perkecambahan konidia dilakukan dengan cara mencampurkan suspensi konidia jamur (kerapatan 1x107konidia/ml) dalam 3\% agar air pada 
suhu $50^{\circ} \mathrm{C}$ (Yulia et al., 2006). Sebanyak $11,5 \mathrm{ml}$ dari campuran yang dihasilkan kemudian dituangkan dengan segera ke dalam Petri dish berdiameter $9 \mathrm{~cm}$ untuk membentuk ketebalan agar yang seragam 2 $\mathrm{mm}$. Setelah dingin, disk agar berdiameter $10 \mathrm{~mm}$ dipotong dari agar-spore plate dengan menggunakan cork borer steril dan empat disk agar diletakkan pada object glass steril. Ekstrak air rimpang lengkuas diteteskan dengan volume $0,5 \mu \mathrm{l}$ pada permukaan disk agar-spore. Sebagai kontrol digunakan akuades steril. Object glass yang sudah diberi perlakuan disimpan dalam wadah plastik steril yang dilapisi kertas saring steril lembap. Wadah plastik kemudian diinkubasikan pada suhu kamar $\left( \pm 28^{\circ} \mathrm{C}\right)$ selama 24 jam. Konidia yang berkecambah diamati dengan menggunakan mikroskop cahaya pada pembesaran 100x. Pengamatan dilakukan dengan menghitung konidia yang berkecambah dibandingkan dengan perlakuan kontrol. Pengamatan dilakukan setelah 24 jam.

\section{Uji Pertumbuhan Benih Kedelai}

Benih diinokulasi Colletotrichum spp. terlebih dahulu kemudian benih yang sudah diberi perlakuan ekstrak air rimpang lengkuas, fungisida, dan perlakuan kontrol ditanam pada wadah-wadah plastik. Kemudian diamati karakter tumbuhnya seperti tinggi tanaman dan jumlah daun. Pengamatan dilakukan setiap 24 jam selama 2 minggu.

\section{Uji Viabilitas Benih}

Sekitar 30 benih kedelai yang telah diinokulasi Colletotrichum spp. dan telah diberi perlakuan ekstrak air rimpang lengkuas pada konsentrasi yang paling baik, fungisida dan akuades diletakkan dan diratakan diantara dua kertas saring yang lembap dan kemudian ditempatkan pada Petri dish. Tingkat perkecambahan kemudian diamati dengan menempatkan Petri dish pada suhu $30^{\circ} \mathrm{C}$. Viabilitas benih diukur dengan menentukan persentase biji berkecambah pada suhu $30^{\circ} \mathrm{C}$ dalam waktu 72 jam (Pandrangi et al., 2007).

\section{HASIL DAN PEMBAHASAN}

Uji Efikasi Ekstrak air Rimpang Lengkuas Terhadap Patogen Colletotrichum spp. pada Benih Kedelai

Terdapat perbedaan persentase kemunculan jamur Colletotrichum spp. pada benih kedelai yang diperlakukan ekstrak air rimpang lengkuas pada konsentrasi yang berbeda (Tabel 1). Semakin tinggi konsentrasi maka semakin sedikit persentase kemunculan jamur Colletotrichum spp. pada benih kedelai.

Tabel 1. Persentase kemunculan jamur Colletotrichum spp. pada benih kedelai pada satu hari setelah inkubasi.

\begin{tabular}{lc}
\hline Perlakuan & $\begin{array}{c}\text { Kemunculan jamur } \\
\text { Colletotrichum spp. } \\
(\%)\end{array}$ \\
\hline 10\% ekstrak air lengkuas & $30 \mathrm{~b}$ \\
30\% ekstrak air lengkuas & $5 \mathrm{~cd}$ \\
$50 \%$ ekstrak air lengkuas & $15 \mathrm{bc}$ \\
$70 \%$ ekstrak air lengkuas & $5 \mathrm{~cd}$ \\
$90 \%$ ekstrak air lengkuas & $0 \mathrm{~d}$ \\
100\% ekstrak air lengkuas & $0 \mathrm{~d}$ \\
Fungisida metalaksil & $5 \mathrm{~cd}$ \\
Kontrol & $100 \mathrm{a}$ \\
\hline Kel
\end{tabular}

Keterangan: Nilai rata-rata yang diikuti huruf yang sama dalam kolom tidak berbeda nyata berdasarkan Uji Jarak Berganda Duncan (DMRT) pada taraf 5\%.

Terdapat anomali data pada konsentrasi ekstrak air lengkuas 30\% dan 50\%, hasil penekanan pada konsentrasi 30\% lebih baik daripada 50\% (Tabel 1). Hal ini dapat terjadi karena sebaran inokulum yang ada pada benih tidak merata. Pada benih kedelai yang digunakan untuk perlakuan dengan konsentrasi 50\% memiliki inokulum yang lebih banyak atau benih yang digunakan relatif tidak sehat sehingga memiliki tingkat kerentanan terhadap patogen yang berbeda. Di luar dari anomali data di atas, hasil dari uji statistik menunjukkan bahwa semua perlakuan pada hari pertama memiliki hasil yang berbeda nyata jika dibandingkan dengan kontrol. Hal ini menunjukkan bahwa ekstrak air rimpang lengkuas dapat menekan pertumbuhan jamur Colletotrichum spp.

Kemampuan ekstrak air rimpang lengkuas dalam menghambat pertumbuhan Colletotrichum spp. pada konsentrasi $90 \%$ dan $100 \% \quad(0 \%$ kemunculan jamur Colletotrichum spp.) lebih tinggi dibandingkan dengan perlakuan fungisida berbahan aktif metalaksil (5\% kemunculan Colletotrichum spp.) meskipun tidak berbeda nyata secara signifikan. Dengan demikian, penggunaan ekstrak air rimpang lengkuas dapat dianjurkan untuk dipakai pada perlakuan benih kedelai karena akan 
lebih aman dalam penggunaan dan efeknya dibandingkan dengan menggunakan fungisida sintetik yang relatif lebih berbahaya bagi kesehatan dan beracun bagi benih kedelai itu sendiri. Kemampuan penekanan pertumbuhan jamur oleh rimpang lengkuas ini sesuai dengan penelitianpenelitian sebelumnya diantaranya yang dilakukan Yulia et al. (2006) tentang keefektifan ekstrak rimpang lengkuas dalam menghambat pertumbuhan patogen lain yaitu ekstrak lengkuas $(500 \mathrm{mg} / \mathrm{ml})$ menghambat sampai $100 \%$ perkecambahan konidia jamur $P$. versicolor dan penelitian stabilitas aktivitas antioksidan ekstrak lengkuas (Juntachote \& Berghofer, 2005), serta ekstrak air dan etanol lengkuas yang menghambat pertumbuhan miselium dan perkecambahan konidia C. gloeosporioides penyebab penyakit antraknosa pada lada (Yulia et al., 2006).

Penggunaan ekstrak air rimpang lengkuas dengan konsentrasi $100 \%$ dapat menekan perkembangan Colletotrichum spp. bahkan menekan kemunculannya hingga $0 \%$ dan dapat melebihi efektifitas dari fungisida metalaksil sebagai pembanding. Meskipun ada kecenderungan efek penekanan kemunculan Colletotrichum spp. yang menurun setelah 24 jam, pada hari kedua ekstrak air rimpang lengkuas dengan konsentrasi 100\% masih berbeda nyata dengan perlakuan kontrol dan tetap lebih efektif (penekanan 100\%) dalam menekan kemunculan jamur Colletotrichum spp. dibandingkan dengan perlakuan fungisida metalaksil (penekanan 65\%).

\section{Uji Penekanan Perkecambahan Konidia Colletotrichum spp.}

Hasil penekanan perkecambahan konidia jamur menunjukkan ekstrak air rimpang lengkuas konsentrasi $100 \%$ efektif menghambat perkecambahan konia Colletotrichum spp. Pada konsentrasi ini, ekstrak air rimpang lengkuas menekan perkecambahan konidia jamur Colletotrichum spp. sampai $76,2 \%$ dibandingkan dengan penekanan oleh fungisida metalaksil sebesar 68\% meskipun secara statistik tidak berbeda nyata. Aktivitas biologi ekstrak tanaman ini telah banyak dilaporkan dalam menghambat perkecambahan spora, menghambat pertumbuhan dan perkembangbiakan patogen, ataupun dalam mematikan patogen secara total (Hay \& Waterman, 1993).

Uji Viabilitas Benih dan Pertumbuhan Tanaman Kedelai
Perlakuan benih dengan ekstrak air rimpang lengkuas konsentrasi $100 \%$ dan perlakuan fungisida metalaksil memberikan perkecambahan benih kedelai sebesar $100 \%$ pada tiga hari setelah inkubasi. Pada perlakuan kontrol, hanya beberapa benih kedelai yang berkecambah (Gambar 1). Hal ini mengindikasikan kemungkinan ekstrak air rimpang lengkuas dan fungisida metalaksil mencegah benih kedelai terinfeksi oleh jamur Colletotrichum spp. dan mengakibatkan kemampuan benih berkecambah yang tinggi. Benih kedelai yang tidak berkecambah pada perlakuan kontrol dapat diperkirakan karena infeksi jamur Colletotrichum spp. pada benih. Konidia jamur Colletotrichum spp. dilaporkan menginfeksi titik tumbuh pada benih kedelai (Semangun, 2004). Ada kemungkinan bahwa ekstrak air rimpang lengkuas menstimulasi perkecambahan benih kedelai. Hasil juga menunjukkan bahwa warna dari kecambah benih kedelai pada perlakuan ekstrak air rimpang lengkuas berwarna lebih hijau dan nampak lebih sehat dibandingkan dengan perlakuan lainnya. Pada beberapa benih kedelai pada perlakuan kontrol, nampak terjadi diskolorisasi pada kecambah setelah inkubasi dimana diskolorisasi ini tidak terdeteksi pada benih yang diperlakukan dengan ekstrak air rimpang lengkuas ataupun fungisida metalaksil. Keberadaan bercak diskolorisasi ini mungkin disebabkan oleh infeksi patogen pada benih.

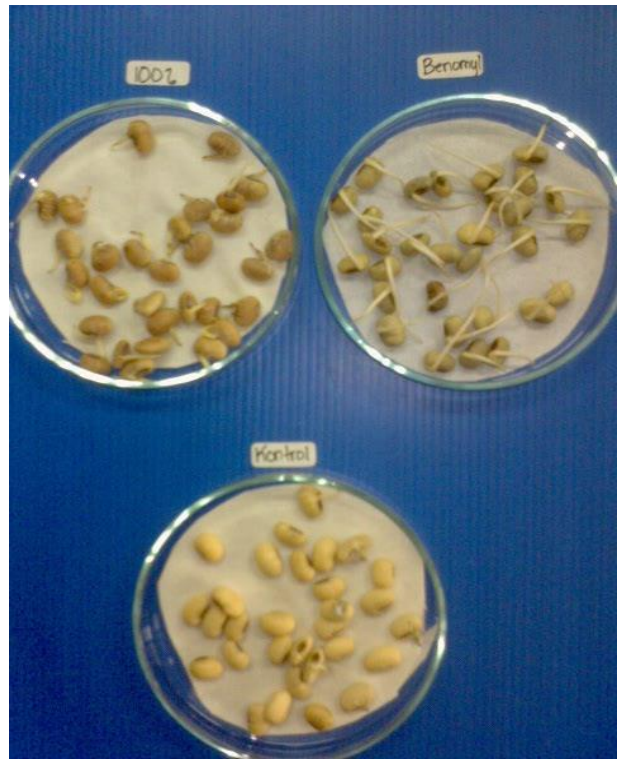

Gambar 1. Perkecambahan benih kedelai pada perlakuan ekstrak air rimpang lengkuas, fungisida metalaksil dan kontrol setelah tiga hari inkubasi. 
Kisaran rata-rata tinggi tanaman kedelai setelah dua minggu setelah tanam adalah 14,89 sampai 17,68 cm dimana tinggi tanaman tertinggi terdapat pada tanaman dengan perlakuan ekstrak air rimpang lengkuas dan tinggi tanaman terrendah terdapat pada perlakuan kontrol. Hasil ini menunjukkan bawah ekstrak air rimpang lengkuas mampu menstimulasi pertumbuhan tanaman kedelai. Namun demikian, tinggi tanaman kedelai ini tidak berbeda nyata secara statistik diantara semua perlakuan. Jumlah daun tanaman kedelai juga tidak berbeda nyata secara statistik diantara semua perlakuan dengan jumlah daun sebesar 8,2, 8,3, dan 7,7 daun per tanaman pada masing-masing perlakuan ekstrak air rimpang lengkuas, fungisida metalaksil dan perlakuan kontrol. Namun demikian, secara kualitas tanaman kedelai pada perlakuan ekstrak air rimpang lengkuas menunjukkan performa yang lebih baik dibandingkan dengan tanaman kedelai pada perlakuan lainnya. Tanaman kedelai pada perlakuan ekstrak ini nampak lebih hijau dengan daun yang lebih lebar dan nampak lebih sehat. Tidak terjadi gejala fitotoksik maupun gejala penyakit rebah kecambah (damping-off) pada tanaman kedelai yang tumbuh. Dengan demikian, ekstrak air rimpang lengkuas ini disamping dapat digunakan untuk mengendalikan infeksi Colletotrichum spp. pada benih kedelai juga diperkirakan memiliki efek pupuk hayati pada pertumbuhan tanaman kedelai.

\section{SIMPULAN}

Ekstrak air rimpang lengkuas yang digunakan dalam perlakuan biji mampu menekan pertumbuhan Colletotrichum spp. pada benih kedelai. Penekanan perkecambahan konidia jamur Colletotrichum spp. tertinggi diperoleh pada penggunaan konsentrasi 100\% sebesar 76,2\% dimana dapat dikatakan lebih efektif daripada fungisida metalaksil. Perlakuan ekstrak air rimpang lengkuas juga mampu meningkatkan pertumbuhan tanaman kedelai yang tumbuh dari biji yang diberi perlakuan ekstrak serta memberikan performa benih dan tanaman kedelai yang lebih baik daripada perlakuan lainnya. Ekstrak air rimpang lengkuas dapat digunakan pada perlakuan benih kedelai karena potensi antijamur dan pupuk hayati yang dimilikinya serta pemanfaatan bahan alami ini akan bersifat aman untuk lingkungan.

\section{DAFTAR PUSTAKA}

Agrios, GN. 1997. Plant Pathology. $4^{\text {th }}$ Ed. Academic Press, Inc. San Diego. California. 635 p.

Barnett, HL and BB Hunter. 1972. Illustrated Genera of Imperfect Fungi. Burgess Publishing Company. Minnesota.

Black, JG. 1999. Microbiology - Principles and Explorations. $4^{\text {th }}$ ed. Prentice-Hall Inc. New Jersey.

Dhingra, OD and JB Sinclair. 1985. Basic Plant Pathology Methods. CRC Press, Inc. St. Paul, Minnesota.

Hartman, GL, JB Manandhar and JB Sinclair. 1986. Incidence of Colletotrichum spp. on Soybeans and Weeds in Illinois and Pathogenicity of Colletotrichum truncatum. The American Phytopathologist Society. Urbana.

Hay, RKM and PG Waterman. 1993. Volatil Oil Crops: Their Biology, Biochemistry, and Production. Longman Scientific \& Technical. Essex.

Juntachote, T and E Berghofer. 2005. Antioxidative properties and stability of ethanolic extracts of holly basil and galangal. Food Chemistry. 92 (2): 193-202.

Kartasapoetra, AG. 2003. Teknologi Benih (Pengolahan Benih dan Tuntunan Praktikum). Rineka Cipta. Jakarta.

Menaka, C, K Vanangamudi, K Prabakar, A Bharathi and $P$ Natesan. 2003. Management of seed borne grain mould disease of sorghum with botanicals. Madras Agric. J. 90(7-9): 553557.

Munkvold, G, L Sweets and W Wintersteen. 2006. Seed Treatment Category 4. Iowa Commercial Pesticide Applicator Manual. Iowa.

Pandrangi, S, MW Elwell, RC Anantheswaran and LF Laborde. 2007. Efficacy of sulfuric acid scarification and disinfectant treatments in eliminating Escherichia coli 0157:H7 from alfalfa seeds prior to sprouting. Food Microbiology and Safety.

Sawatwanich, A, P Thobunluepop, S Dheeranupattana, C Jatisatienr, SVearasilp, E Pawelzik and A Jatisatienr. 2007. Application of Eugenol for Coating Soybean Seeds as Fungal Control. International Agricultural Research for Development. 
Semangun, H. 2004. Penyakit-Penyakit Tanaman Pangan di Indonesia. Gadjah Mada University Press. $449 \mathrm{hlm}$.

Shovan, LR, MKA Bhuiyan, JA Begum and Z Pervez. 2008. In Vitro control of Colletotricum dematium causing anthracnose of soybean by fungicides, plant extract and Trichoderma harzianum. Int.J.Sustain. Crop Prod. 3 (3): 10-17.

Sinaga, E. 2003. Alpinia galangal [L.] Willd. Pusat Penelitian dan Pengembangan Tumbuhan Obat UNAS. Tersedia online pada http://www.iptek.apjii.or.id. (Diakses Maret 2010).

Suryanarayana, D. 1979. Seed Pathology. Vikas Publishing House, Ltd. New Delhi.

Sutopo, L. 1985. Teknologi Benih. CV. Rajawali. Jakarta.

Yuharmen, Y Eryanti dan Nurbalatif. 2002. Uji aktivitas antimikroba minyak atsiri dan ekstrak methanol lengkuas (Alpinia galangal). Tersedia online pada www.unri.ac.id. Diakses Juni 2010.

Yulia, E. 2006. Aktivitas anti jamur minyak esensial dan ekstrak beberapa tanaman keluarga zingiberaceae dan poaceae terhadap jamur Pestalotiopsis versicolor penyebab penyakit hawar daun pada tanaman kayu manis (Cinnamomum zeylanicum). Jurnal Agrikultura 17 (3): 224231.

Yulia, E, WA Shipton and RJ Coventry. 2006. Activity of Plant Oils and Extracts against Colletotrichum gloeosporioides. Plant Pathology Journal 5 (2): 253-257.

Yulia, E, WA Shipton and RJ Coventry. 2008. Antifungal activity of selected aromatic and volatile oils and plant extracts on putative plant pathogens. Journal of Medicinal and Aromatic Plant Sciences. 30: 109-112. 